\title{
Strategic Leadership as Determinant of Strategic Change: A Theoretical Review and Propositions
}

\author{
Ayi Ahadiat* \\ Fakultas Ekonomi Universitas Lampung
}

\begin{abstract}
The strategic change is an issue that closely related to strategic leadership. As this paper elaborates how strategic leadership determines the strategic change, the elaboration of both concept and their relationship are presented through propositions that are developed from the modified Hambrick's model. Strategic leadership that causes strategic change in terms of strategic process and content within environmental and organizational context will lead to organizational performance as an ultimate outcome.
\end{abstract}

Key words: Strategic change, strategic leadership, TMT, and performance.

\section{Introduction}

The hypercompetitive and complex environment of business put a lot of pressure for organizations to adjust in timely manner (D'Aveni 1994). In other words, an organization has to seek good momentum to change comfortably otherwise, it will be forced to change to fit to the environment. To be remain survive, sustainable and competitive, an organization must be alert and flexible toward any changing that take place in its environment. Organizations that do not competitive will often begin a gradual downward trend in financial performance and need to be revitalized for continued survival (Landrum et al 2000).

An organization tends to be inertia once it has achieved fitness or alignment between strategy with its structure, with other aspects like leadership, support system, and leadership, and external environment. An organization's alignment with its external environment is defined as the "fundamental pattern of present and planned resource deployments and environmental interactions that indicate how the organization will achieve its objectives" (Hofer \& Schendel 1978). The demand to change occurs when the alignment is no longer exists. Strategic change is defined as the changing of strategic group from one to another in different time (Smith \& Grim 1987). In order to gain optimal benefit from organization turnaround or renewal, change must be made as a strategic change. Changes will begin from the strategy formulation through implementation and control.

From the process point of view, crafting a strategy is not an easy task for managers although he can chose a role as coordinator, coach, rational actor, architect, or as 
a judge (Bourgoeis III \& Brodwin 1984). However, the implementation and control of strategy are other uneasy tasks as well. Implementation of strategy is usually equipped by the changes or revitalization agenda on organization structure in order to build a capable organization, allocating resources, establishing supportive police, exercising strategic leadership, shaping corporate culture to fit strategy, tying rewards to achievement of key strategic targets, installing support systems, and instituting best practices for continues improvement (Strickland \& Thompson 2001). From those agenda the core determinant of change that can be identified is strategic leadership.

When an organization is in a need of strategic change or turnaround, charismatic leadership or transformational leadership put in charge. Effective transformational leader are often capable of communicating a vision and mobilizing the energy necessary for changes (Bass 1985; Landrum et al. 2000). Many organizations also rely on team building in implementing the strategic change to accomplish organization goals. The organization grant increasing amount of authority and responsibility to these team allowing them to be self-managed to develop strategic plan and implementing the strategic change (Emery \& Purser 1996).

Chief of executive officer (CEO) is known as strategic leader of the corporation who reside in the peak of organization structure. However, he or she is not alone in many occasions accompanied by top management team (TMT). Hence, the importance of the role of CEO and TMT as strategic leaders in managing the strategic change of an organization will be elaborated in this paper. The study of strategic leadership had been neglected as a subject of empirical investigation is ironic since the study of effective organization policies and strategies has been one of the most prominent foci of business school education ever since the founding of business schools: Wharton in 1891 and Harvard in 1908 (House \& Aditya 1997).

In this paper, the conceptualization of strategic change, leadership and strategic leadership are systematically provided in order to facilitate the proportions development. In conclusion, there will be a summary of theoretical review and discussion and the recommendation for further empirical study.

\section{Literature Review and Hypothesis Development}

\section{Conceptualization of Strategic Change}

Rajagopalan and Spreitzers (1996) recognized there are three different perspectives that can be found in research of strategic change, namely, rational, learning and cognitive perspective. Strategic change is defined according to those three perspectives. Rational lens perspective defines strategic change as a unitary concept measured through discrete changes in a firm's business, corporate, or collective strategies. According to the learning lens perspective, strategic change is 
viewed as an iterative process; managers effect changes through a series of relatively small steps designed to probe the environment and the organization. And in the cognitive lens perspective, the same definition of strategic change used in the learning lens perspective (i.e., a combination of changes in the content of strategy as well as accompanying organizational and environmental conditions) is generally employed. These three perspectives are integrated into a comprehensive perspective (Rajagopalan \& Spreitzers, 1996). Changes in strategy must match the requirements of a firm's environmental external and internal context in order to be successful. However, when changes in strategy do not match the requirements of the context or not lead to positive organizational outcomes (economic and/or noneconomic), these changes cannot be diagnosed by the rational lens perspective as maladaptive responses but rather by leadership and cognitive perspectives. The learning and cognitive lens perspectives provide value to help researchers understand (a) why different firms respond differently to a similar context (because of different cognitions and actions) and (b) how firms can maximize the effectiveness of their adaptive responses (through different managerial actions aimed at the environment and/or the organization).

Change, one type of event, is an empirical observation of difference in form, quality, or state over time in an organizational entity. To understand the management of change, Rajagopalan and Spreitzer (1996) classify the strategic change in two schools, namely content and process school, while Pettigrew (1987) proposes a framework of analysis interlinking between the content, context, and process of strategic change, as shown in figure 1. The framework formulates management of strategic change involving consideration of not only context of a chosen strategy, or even of the analytical process which reveals various context alternatives, but also the management of the process of change, and the contexts in which it occurs (Pettigrew 1987). Two aspects of context are considered: the inner and outer contexts of the firm. The inner context refers to internal environment of organizational aspects such as structure, culture, and political context inside the firm. The outer context refers to external environment such as economic, business, industry, and political and societal formation in which the firm operates.

The strategic change may also be seen in terms of its antecedents and consequences. Ahadiat (2004) elaborated the antecedents and consequences of strategic change by using modification of the integrative framework or multi-lens perspective (rational, cognitive and learning perspective), as shown in following model. 


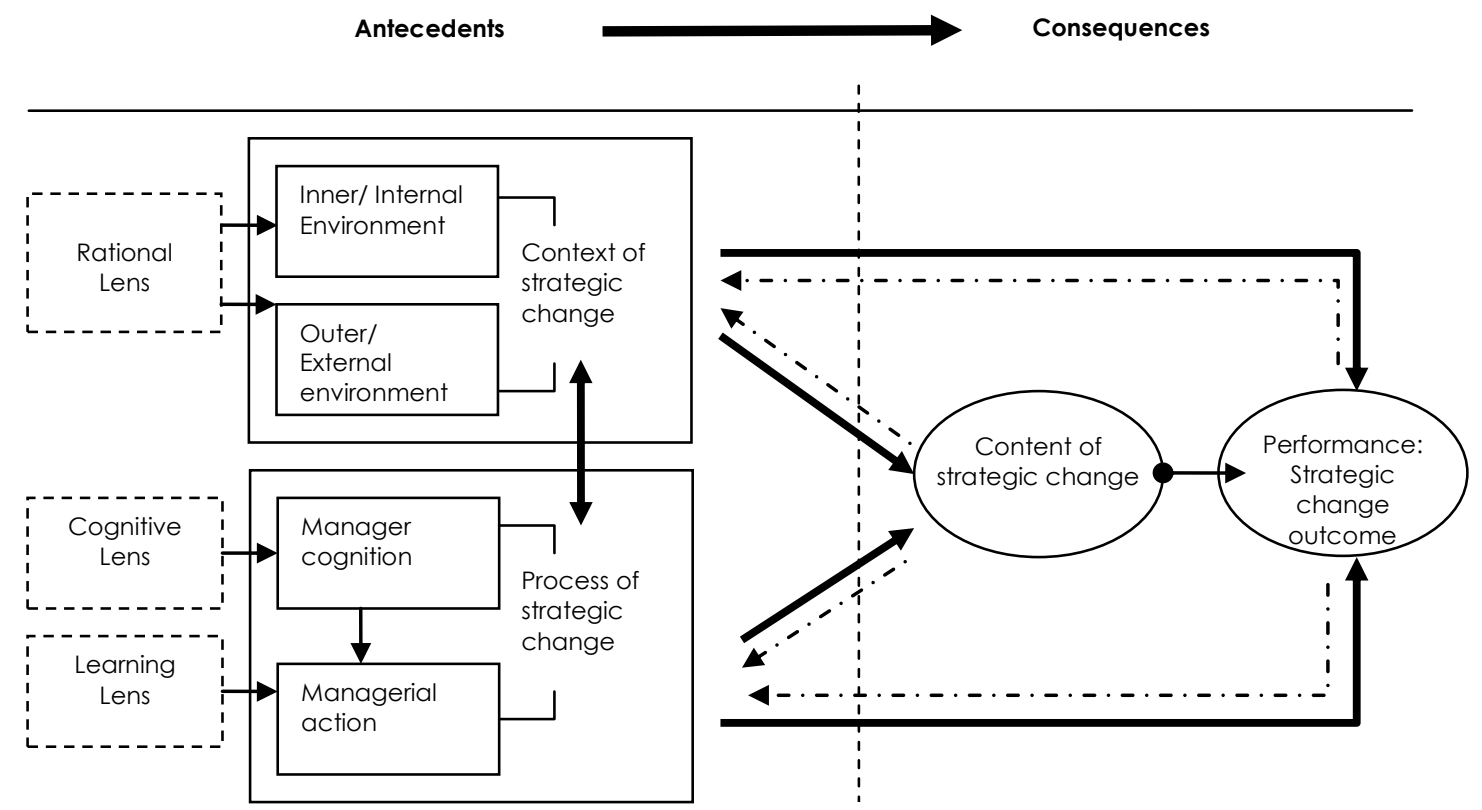

Figure $1 \quad$ Integrative Framework of Strategic Change Analysis: Multi-lens Perspective (Ahadiat, 2005)

The antecedents of strategic change, which can be identified, are the process and context of strategic change. The process of strategic change takes place through manager cognition and managerial action (Rajagopalan \& Spreitzer 1996). The context, in which strategic change takes place, consist of outer or the external environment and the inner or internal environment of the organization (Pettigrew 1987). In this section, the process of strategic change that follows cognitive and learning lens and the context of strategic change that follows rational lens perspective will be elaborated.

The consequences of strategic change that directly caused by context and process aspects is the content of strategic change. Subsequently, the content of strategic change will take a role as mediator that result further consequence so called outcome or performance of the organization.

In term of content of strategic change, Mintzberg and Westley (1992) argue that organizational change is change in the state of the organization while strategic change is change in the direction of the organization, and that these two spheres of change occur at different levels. Strategic change can occur at two levels, i.e., the conceptual level and the concrete level. Conceptual change involves the vision and positioning of the organization, whereas concrete change involves the programs and facilities/products (Figure 2). 
Figure 2 The Change Cube

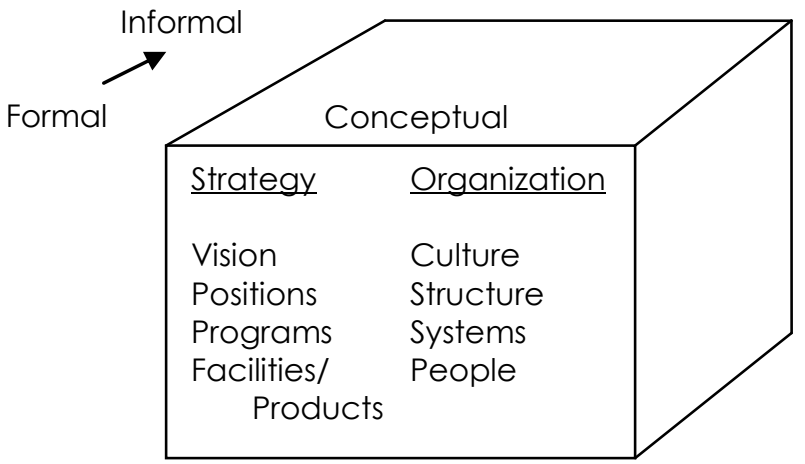

Concrete

Source: Mintzberg, et al. (1998) \& Mintzberg and Westley (1992)

Change at the conceptual level may not be accompanied by changes at the concrete level. However, for strategic change to be effective, changes should take place at both levels. Where conceptual change is accompanied by concrete change, a deductive change has occurred. If the change is initiated at the concrete level leading to changes at the conceptual level, an inductive change has occurred. This framework does not, however, discount the influence of the state of the organization, e.g., culture and structure, on the strategy.

Some organizational theorists argue that not all the components of strategy may change uniformly. For example, Laughlin (1991) suggests that if change involves only the physical aspects, i.e., programmes and facilities of the organization, then little change has occurred, while if change occurs to the paradigm, i.e., vision and position of the organization, then change that is more fundamental has taken place. These changes are referred to as first order and second order changes, respectively. From the organization point of view, cultural and structural changes are considered as fundamental change, while system and people changes are considered as technical one.

Changes to strategy may be planned in formal manner, involving the collection and analysis of all the data available, and considering all scenarios. The planning process may lead to an intended strategy, which incorporates patterns of decisions that organizations plan to execute. The strategy that is ultimately realized may be what was planned, i.e., deliberate strategy, or it could be what was not initially intended, i.e., emergent strategy (Mintzberg \& Waters 1985). The planning perspective adopts a rational approach to strategic change on the grounds that this gives organizations a sense of direction, enabling the allocation of resources to the most promising courses of action and encouraging long term thinking and commitment (De Wit \& Meyer 1998). Contrary to the planning perspective, the incrementalist perspective 
posits that planning is not suitable for non-routine activities, and that new strategies emerge over time as managers proactively piece together a viable course of action or reactively adapt to unfolding circumstances. Strategists under this perspective are inventors or innovators who question the current paradigm and explicate a learning orientation. The strategy formation process is an iterative process of action, where strategies are considered and reconsidered on the basis of emerging evidence. Two types of incrementalism are identified, muddling through, which is reactive and ad hoc, and logical incrementalism, which is a reasonable, well considered, proactive approach to strategy formation. These incremental kinds of change are seen as informal change.

The subsequent consequence of strategic content change is whether performance becomes better or worse. Performance, as an outcome or a impact of strategic change, rationally, can be classified into economic and non economic outcome. The relationship between strategic change and organizational outcomes in a noneconomic measure examined TMT turnover (Wiersema \& Bantel 1993) and organizational survival (Haveman 1992; Singh et al. 1986). Based on compilation done by Rajagopalan and Spreitzers (1996), rational lens studies have been focused almost exclusively on financial or economical performance (measures included operating ratio, return on assets, return on investment, growth, productivity, production time, etc.) and organizational survival. In spite of the large samples and statistical methods used in these studies, findings were also equivocal. In some studies, strategic change enhanced financial performance (Hambrick \& Schecter 1983; Haveman 1992; Zajac \& Kraatz 1993) and the likelihood of firm survival (Haveman 1992). In other studies, similar strategic changes reduced financial performance (Graham \& Richards 1979; Jauch, Osborne, \& Glueck 1980) and the likelihood of firm survival (Singh et al. 1986). Yet in another set of studies, either no relationship was found (Kelly \& Amburgey 1991; Zajac \& Shortell 1989) or mixed relationships (Smith \& Grimm 1987) were found between the direction of strategic change and firm profitability. Finally, Hambrick and Schecter (1983) found that the relationship between changes in strategy and improved financial performance was contingent on the type of change and the type of industry environment. Economic performance improved if they are accompanied by executive successions and personnel changes (Meyer 1982; Tushman et al. 1985) and changes in organizational structures and processes (Barr et al. 1992; Greiner \& Bhambri 1989; Miller \& Friesen 1980; Nutt 1987; Schendel et al. 1976; Simons 1994). Strategic change related to non-economic outcomes such as perceived managerial effectiveness (Simons 1994; Hambrick 1989), commitment and morale (Greiner \& Bhambri 1989), and perceived quality of change (Nutt 1987), fulfillment of stakeholder needs (Hambrick 1989) and enduring changes in ideology (Meyer 1982).

As this paper will discuss more about strategic leadership in relation to strategic change, it will be worth doing if the conceptualization of leadership in fundamental 
sense is presented as well. In subsequent sections, strategic leadership and its causality to strategic change will be presented to precede the propositions.

\section{Conceptualization of Leadership under Neo-Charismatic Theories}

Theories that fall under genre of neo-charismatic leadership theories (transformational, visionary, attributional, and value-based leadership) have important and influential role in the practical world. Since Burn (1978) contrasted the transformational leadership with transactional leadership, it is worth doing to begin the elaboration with transactional leadership. For Burn (1978), the transactional political leader motivated followers by exchanging with them rewards for service rendered. Burns (1978) asserted "transactional leaders approach followers with an eye to exchanging one thing for another: jobs for votes or subsidies for campaigns contributions." Bass (1985) formulate a transactional leadership model that described the most important variables affecting the dependent outcome of expected effort and performance. The leader recognizes the role the follower must play to attain the outcomes desired by the leader. The leader clarifies this role. This clarification provides the follower with confidence necessary to carry it out to meet the objectives. In parallel, the leader recognizes what follower needs and clarifies for the follower how these needs will be fulfilled in exchange for the follower's satisfactory effort and performance. This makes the designated outcome of sufficient value to the follower to result in his effort to attain the outcome. Zaleznik (1983) asserted that managers are transactional leaders. They tend to survey their subordinates' needs and set goals for them on the basis of the effort they can rationally expect from their subordinates. The transactional leader pursues a costbenefit, economic exchange to meet subordinate's current material and physic needs in return for "contracted" service rendered by subordinate. The opposite side of transactional leadership is transformational leadership.

Another theory under the genre of neo-charismatic leadership is the attributional theory of leadership. This theory was developed by Conger and Kanungo (1987) on the assumption that charisma is an attributional phenomenon. Followers attribute certain charismatic qualities to a leader based on their observations of the leader behavior. The features of leaders that were identified by Conger and Kanungo (1987) are extremity of the vision, high personal risk, use of unconventional strategies, accurate assessment of the situation, follower disenchantment, communication of self-confidence, and use of personal power.

Visionary theory of leadership is one of member of neo-charismatic leadership was developed by Bennis and Nanus (1985). They identified the way chief executive officers reshape organizational practice to adapt the environmental changes, how they build the employee confidence, and mastery of new ways of doing things. Three aspects had been identified are developing vision, developing commitment and trust, and facilitating organizational learning. A clear and appealing vision 
serves some important functions. One function is to inspire followers by giving their work meaning and appealing to their fundamental human need to important, to feel useful, and to be part of worthwhile enterprise. Second function of a vision is to facilitate decision-making, initiative, and discretion by employees at all levels. Knowing organization's central purpose and objectives helps people determine what is good or bad, important and trivial.

Tichy and Devanna (1986) did another visionary leadership research. They conducted the study that focus on leaders of large organization who must transform and renew those organization to adapt a successfully to a changing and increasingly competitive environment characterized by a rapid technological change, widespread social and cultural change, intense competition from foreign companies, and increasing interdependence among the economies of different nations. They identified the processes occur when leaders transform organizations. The processes began with recognition of the need for change, followed by creation of a new vision and then institutionalization of change.

An effort to integrate the neo-charismatic leadership, e.g. charismatic, transformational, and visionary leader theories, was shown by House and Shamir (1993). They argued that the theories of neo-charismatic paradigm that differ with respect to their leader behavior, need to be reconciled or else the contingencies under which behavior are important to be specified. Lindhom (1990) argues that the term charisma refers primarily to socially undesirable and destructive leadership. Howell and House (1992) disagree, and distinguished between two kinds of charismatic leadership: personalized (self aggrandizing, exploitative, authoritarian) and socialized (altruistic, collectively oriented, and egalitarian). Bass (1985, 1997) argued that transformational theory of subsumes charismatic theory. While House and Shamir (1993) see transformational, charismatic, visionary leadership as essentially the same, in that all of these theories include among their independent variables the affective states of followers, and all of them stress leader behavior that is symbolic, appealing to follower emotions, and highly motive arousing.

House et al (1996) came up with different perspective to refine and extent the 1976 theory of charismatic leadership (House 1977). The proposed the Value based theory of leadership, which specifies the leader motive profile, and leader selfconfidence and conviction as predictors of charismatic leader behaviors. This theory also specifies a set of contextual conditions which facilitate the enactment of leader dispositions and the emergence and effectiveness of value based leadership. More specifically, it is predicted that the emergence and effectiveness of value based leaders will be enhanced when the environment involves a high degree of stress and uncertainty, the organizational task is closely related to dominant values of the society, the situation offers at least some opportunity for "moral" involvement, goals cannot be easily specified and measured, when the leader cannot link extrinsic rewards to individual performance. 
The diversity of theoretical conceptions with regard to leadership and equivocal findings in empirical research produced tension to create a new direction of research. The answer to the ambiguity of leadership is that researchers have not distinguished between operating leader and strategic leader. Schendel (1989) in Special Issue of Strategic Management Journal (SMJ) aroused this issue, just 10 years after the establishment of the SMJ. As the this paper is to provide a bridge between leadership and strategic management literature, the topic of strategic leadership is a central. In the subsequent section of the paper, one can see the implication of strategic leadership to strategic change in the organization.

\section{Conceptualization of Strategic Leadership}

Strategic leadership has its roots in genre of neo-charismatic leadership theory. On the conceptualization of strategic leadership, Hambrick (1989) mentioned that there is no agreement on the construct investigated concerning top manager, various terms had been used are strategic leadership, executive leadership, upper echelon, top manager, just plain leadership. However, for uniformity he proposed to use the name of construct strategic leadership. Because it connotes management of an overall enterprise, not just a small part; and it implies substantive decision-making responsibilities, not only the interpersonal and social dimensions typically with the word of 'leadership' alone, which tend to be equated with a series of inquiries into low level supervisory managers. Upper echelons, a term set forth by Hambrick and Mason (1984) has limitations in referring primarily to the association between executive characteristics and organizational outcomes, or only a part of the domain of strategic leadership.

Similar tone with what had been mentioned by Schendel (1989) in distinguishing the strategic leadership with non-strategic one proposed by House (1996). House has argued that distinctions between management, supervisory leadership, and general or strategic leadership are important because they help to understand why academic literature entitled "leadership" has been criticized as irrelevant to the solution of practical problems, and has so infrequently been consulted by practicing managers and applied to this problems of leading organizations or societies. House and Aditya (1997) distinguished between strategic and supervisory leadership. Strategic leadership is directed toward giving purpose, meaning, and guidance to organizations. This is accomplished by the provision of a vision of the organization, which has inspirational appeal to members of the organization and to external constituencies on which it is dependent.

Strategic leadership includes: making strategic decisions concerning the products and services of organizations and markets; selection of key executives; and allocation of resources to major organizational components; formulation of organizational goals and strategy; providing direction for organization with respect to the organization's domain; conceptualizing and installing organizational designs 
and major infrastructures, such as compensation, information, and control systems; representing the organization to critical constituencies such as representatives of financial institutions, government agencies, customer interest groups, and labor; negotiating with such constituencies for legitimacy and resources. Supervisory leadership is defined as behavior intended to provide guidance, support, and corrective feedback for the day-to-day activities of work unit members. Supervisory leadership consists essentially of the task- and person-oriented leader behaviors specified in the leader behavior paradigm. It is possible for managers to be leaders and leaders to be managers. Managers become leaders by providing vision, direction, strategy, and inspiration to their organizational units, and behaving in a manner that reinforces the vision and its inherent values. Leaders often must perform many of the management functions (House \& Aditya 1997).

Before further elaborate what is strategic leadership and how the construct operate, Minztberg (1973) and Kotter (1982) identified some feature of the top management jobs, which influence its researches. First, the strategic leader is concerned with both the external and internal spheres. A major job is to align the organization with the current and expected external environment-technology, market trends, regulatory forces, competitor actions. Second, the strategic leader is embedded in ambiguity, complexity, and information overloaded. Third, strategic leadership task is multifunctional - cutting across marketing, operations, finance, and other activities. Finally, the strategic task leadership, in contrast to leading a smaller departmental subunit, largely involves managing through others. Strategic leader must rely on intermediaries for managing daily affairs of the enterprise. To see how strategic leadership fit into the overall domains of strategy and organization theory, Hambrick (1989) provide a framework for mapping strategic leadership research, as seen in following figure. 


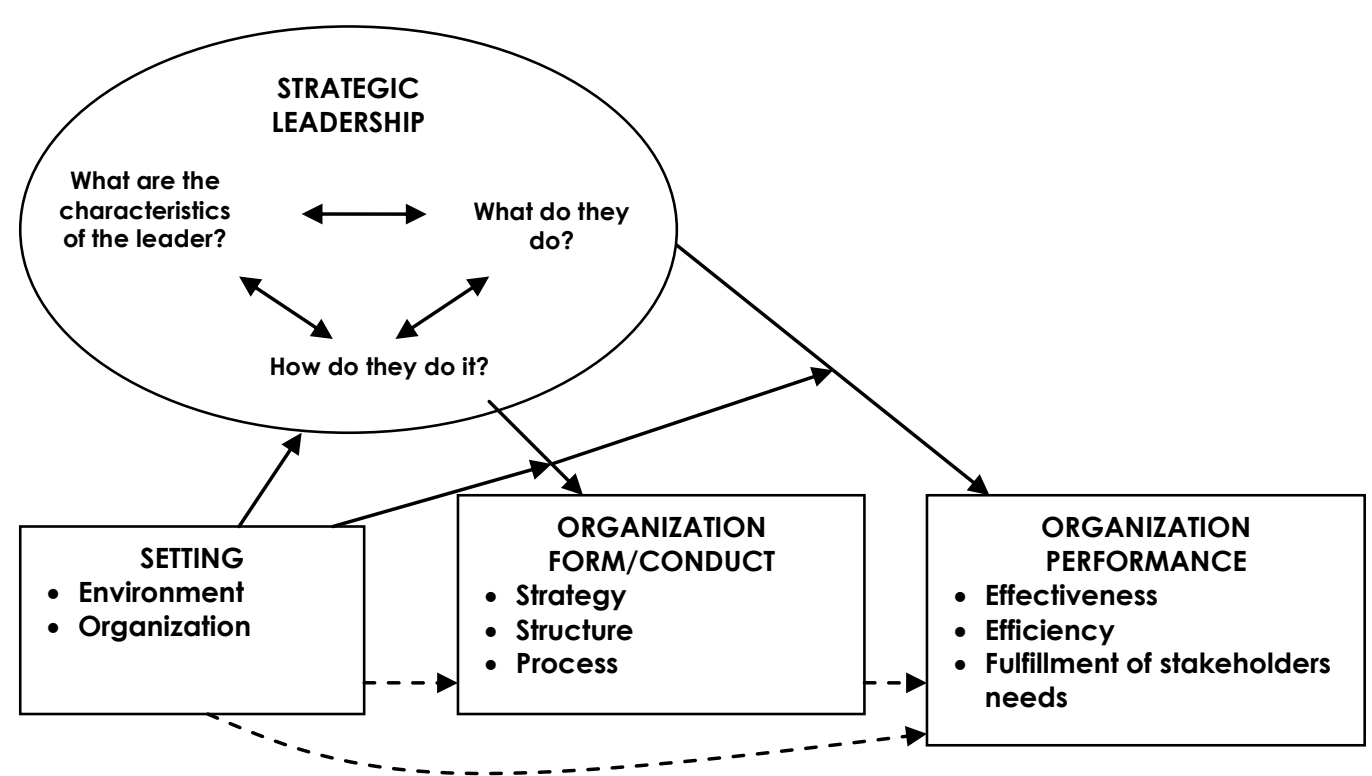

Figure 3

Fitting strategic leadership into the strategy framework (Hambrick, 1989)

Figure 3 portrays theoretical connection between strategic leadership with other element that includes in strategy research field: setting, organization form and conduct, and organization performance. Settings are exogenous factors which describe the environment (e.g. industry growth rate or concentration ratio) or organization (e.g. size or diversity). Organizational form and conduct are characteristics of the firm, which include its strategy, structure, and process. Performance is the consequences of organizational form/conduct can be described as effectiveness, efficiency, fulfillment of stakeholders needs (Hambrick, 1989). Apart from three elements, if one sees the role of top manager in outcome generating, in shaping the organization structure, and installing vision, values or culture, then strategic leadership can be considered as fourth element of research of strategy.

From the interactions among four elements, there are six broad classes of research, which closely related to strategic leadership. First, setting affect strategic leadership. The strategic leader recruitment can be from internal organization or from outside organization. Industry factors, diversification posture, and size of firm determine CEO behavior. Successful corporate leaders who give direction to the organization in a strategic sense frequently do so by providing an image or pattern of thinking in a way that has meaning for those directly involve (Quinn, 1980). This reflected in part in Selznick (1957) conception of leadership as involving the embodiment of organizational values and purpose. Strategic leadership, in effect, involves providing a conception and direction for organizational process that goes above and beyond 
what is embedded in the fabric of organization as a structure, i.e. a reified and somewhat static pattern of meaning (Smircich \& Morgan 1982).

Second, strategic leadership affect organization form and conduct. As Hambrick and Masson (1984) argued that organization is a reflection of top manager, value, cognitions, and interpersonal dynamics affect ultimate choice in terms of strategy, structure, and process of organization. Third, strategic leadership affects organizational performance. The characteristics of CEO can be best predictor for organization performance or failure (e.g. prior track record or caliber and scope of influence). Fourth, certain aspects of strategic leadership affect other aspects of leadership. CEO demographic backgrounds (education, tenure, experience, and race) are important facets that tend to correlate each other in affecting the organization performance. Fifth, the association between strategic leadership and form/conduct depends on setting. The CEO characteristics and behavior may not have uniform effects in all contexts. Certain setting may enhance or restrict the amount of executive impact (Hambrick and Finkelstain, 1987). Sixth, association between leadership and organizational performance depends on the setting. This contingent perspective asserts that there is no universally ideal set of executive characteristics or behavior. Rather, leadership must 'fit' the setting in order to yield high performance. Hambrick (1989) also provide illustrative dimensions of strategic leadership, as seen in following table1.

The study of strategic leadership focuses on executives or CEOs who have overall responsibility for an organization. Until only recently, this topic has been largely unresearched. Prior to about the mid 1980s, there were very few empirical studies of the strategic leadership process or strategic leader behavior (Finkelstaein \& Hambrick 1996). However, many strategic leadership studies are conducted through the assessment of how TMT plays its role in conducting the organization. Research on TMT is assessed in terms of diversity (Hambrich \& Mason 1984; Keck 1991; Hambrick \& D'Aveni 1992; Michael \& Hambrick 1992; O'Reilly \& Flatt 1989; Smith et al. 1994; Finkelstain \& Hambrick 1990; Michael \& Hambrick 1992; Grimm \& Smith 1991; Wiersema \& Bantel 1992), group process (Frederickson 1984; Frederickson \& laquinto 1989; Frederickson \& Mitchell 1984; Eisenhardt 1989; Flood et al. 1997; Eisenhardt \& Bourgeois 1988) and consensus (Knight et al. 1999; Hambrick \& Mason 1984, and; Day \& Lord 1992). TMT refers to the theory of upper echelons suggests that executives will make decisions that are consistent with their cognitive base (Hambrich \& Mason 1984) or executive orientation (Finkelstein \& Hambrick 1996), which consists of two elements: psychological characteristics (including values, cognitive models, and other personality factors) and observable experiences. A fundamental principle of upper echelons theory is that observable experiences (i.e. demographic measures) are systematically related to the psychological and cognitive elements of executive orientation (Knight et al. 1999). 
Table 1

Illustrative dimensions of strategic leadership

What are the characteristics of the leader?
Demographics
Tenure
Age
Functional background
Education
Socio-economic background
Financial wealth
Ownership position

What they do?

Think

Create/Envision

Decide

Communicate/Interact

Signal/Symbolize

Allocate their time

How do they do it?

Speed

Explicitness

Style

Formality

Politicization

Team Heterogeneity

Team Size

Knowledge

Skills

Aptitudes

Personalities

Values

Cognitive Style

Openness

Source: Hambrick (1989)

Diversity is central to TMT researches. TMT diversity or heterogeneity is the extent to which a top management team is heterogeneous with respect to members demographic and cognitions. The diversity type can be differentiated in terms of job relatedness (Miliken \& Martins 1996), functional background, education level, tenure, and age (Simons et al. 1999). As a continuation of strategic leadership conceptualization, the subsequent section will discuss the causal relationship of strategic leadership and strategic change.

\section{Causal Relationship between Strategic Leadership and Strategic Change}

After elaborating the concept of strategic change by showing its antecedents and consequences and concept of strategic leadership, to see how strategic leadership relate to strategic change and organizational outcome present paper reformulate Hambrick (1989) framework. The reformulation is done by raising the causality of strategic leadership toward strategic change content, process, and outcome. The modeling of causality can be seen in following figure. 


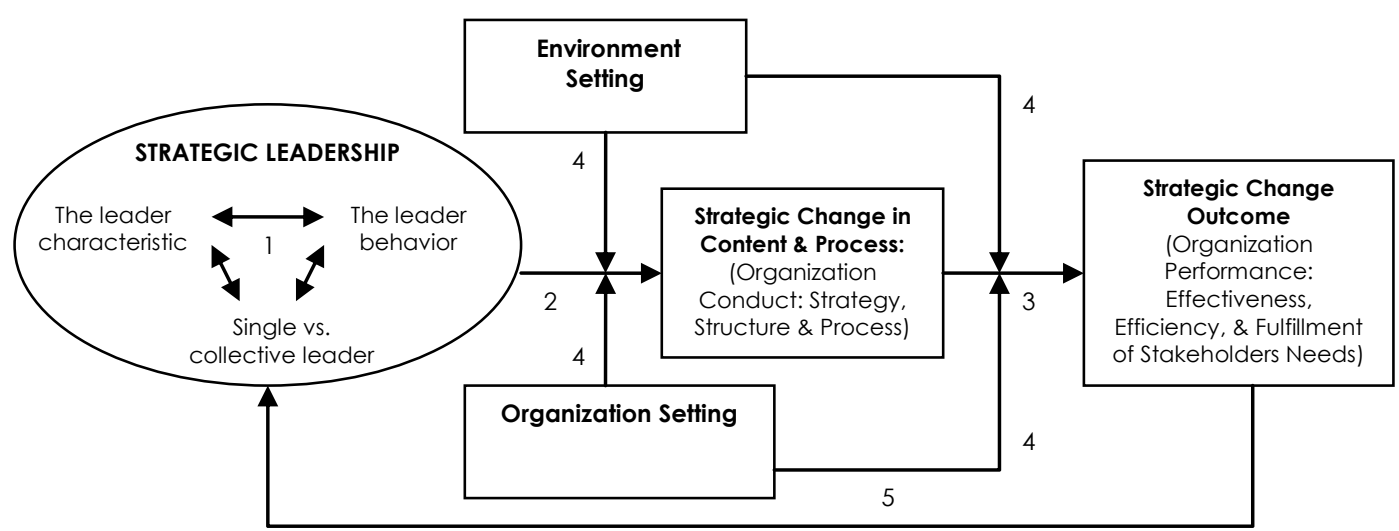

Figure 4

Strategic leadership causality on strategic change

By looking from causality of independent role of strategic leadership and dependent role of strategic change content and outcome, several propositions will be proposed in this section are as follows.

Proposition 1a: Strategic leaders are characterized by vision, transformative orientation, and charisma and supervisory leaders are characterized by transactional orientation.

Proposition 1b: Visionary, transformative and charismatic strategic leaders have higher influences in strategic change than transactional or supervisory leaders.

Proposition 1c: Strategic leaders will behave more toward person oriented rather than task oriented either individually (a CEO) or collectively (a TMT).

Proposition 1d: TMT performs better than individual leader in managing the strategic change and heterogeneous TMT performs better than homogenous TMT in managing the strategic change.

Proposition 2a: Strategic leaders involve in managerial process of strategic change from goal setting (vision, mission, objective, or aim), strategy formation, and implementation to strategic control.

Proposition 2b: Strategic leaders manage strategic change to improve organization conduct through better implement the strategy, structure, and managerial process. 
Proposition 2c: Strategic leader change (CEO or TMT change) will be likely to promote a strategic change (strategy content, i.e. structure and managerial process).

Proposition 3: $\quad$ Strategic change content and process or change in organization conduct in terms of strategy, structure, and process will result in strategic change out come or organizational performance in terms of effectiveness, efficiency, and fulfillment of stakeholders needs.

Proposition 4: Environmental and organizational setting will influence strategic leader in managing the process of strategic change and will influence the strategic change outcome or organizational performance in terms of effectiveness, efficiency, and fulfillment of stakeholders needs. The better alignment of strategic change process and content the higher organizational performance will be accomplished.

Proposition 5: Subsequently, the organization performance will shape future strategic leader characteristics and behavior, and the way they lead (individual or team).s

\section{Conclusion}

This paper attempt to elaborate the concept of strategic leadership and strategic change and assess the causal relationship between these two constructs. The body of literature of leadership has shown not only an ambiguity but also has not distinguished between strategic leadership and supervisory leadership until 1989 as well. Therefore, as one effort it is important to integrate concept and clarify the classification to achieve the unified concept. Another effort of the paper is to see how strategic leadership plays a role as the determinant of strategic change. The function of strategic leadership as determinant of strategic change can be seen in proposed propositions. Based on the propositions, strategic leadership characteristics, behavior and individuality or collectivity are main determinant of strategic change content and process contingent on environmental and organization setting. Furthermore, the successful influence of strategic leadership on strategic change can be as best predictor of organizational outcome. As this paper provides only propositions, it is necessary to test these propositions empirically in various organizational and environmental setting in order to obtain constructs validity and generalizability of the model. As this paper provide only propositions, it is necessary to test them empirically in various organizational and environmental settings. 


\section{References}

Ahadiat, A. 2005. Assessing antecedents and consequences of strategic change: A theoritical review. Paper presented at Indonesian Business Management Conference, Prasetya Mulya Business School, Jakarta

Bass, B. M. 1985. Leadership and Performance Beyond Expectations, The Free Press, New York, NY.

Bass, B.M. 1997. Does the transactional-transformational paradigm transcend organizational and national boundaries? American Psychologist, 22 2: 130142

Bennis, W. G. and Nanus, B. 1985. Leaders: The Strategies for Taking Charge, Harper \& Row, New York, NY

Burns, M. J. 1978. Leadership, Harper, New York, NY.

Conger, J.A. and Kanungo, R. N. 1987. Toward a behavioral theory of charismatic leadership in organizational settings, Academy of Management Review, Vol. 12 No. 4 pp. 637-47

D'Aveni, R. A. 1994. Hypercompetition: Managing the dynamics of strategic maneuvering. New York: Free Press.

Day, D. V. and R. G. Lord 1992. 'Expertise and problem categorization: The role of expert processing in organizational sense-making', Journal of Management Studies, 29, pp. 35-47.

De Wit, B and Meyer, R. 1998. Strategy: Process, Content, Context. London: International Thomson Business Press.

Eisenhardt, K. M. 1989. Making fast strategic decisions in high-velocity environments. Academy of Management Journal, 32: 543-577.

Eisenhardt, K. M., and L. J. Bourgeois III. 1988. Politics of strategic decision making in high-velocity environments: Toward a midrange theory. Academy of Management Journal, $31:$ 737-770.

Emery, F. and Purser, R. 1996. The Search Conference: A Powerful Method for Planning Organizational Change and Community Action, Jossey-Bass, San Fransisco, CA

Finkelstein, S. and Hambrick, D.C. 1996. Strategic Leadership: Top Executives and Their Effectson Organizations, West, Minneapolis/St. Paul.

Finkelstein, S. and Hambrick, D. C. 1990. Top-management team tenure and organizational outcomes: The moderating role of managerial discretion. Administrative Science Quarterly, 35: 484-503.

Flood, P. C., C. M. Fong, K. G. Smith, P. O. O'Regan, S. Moore and M. Morley 1997. Top management teams and pioneering: A resource based view, International Journal of Human Resource Management, 8, pp. 291-306.

Fredrickson, J. W. 1984. The comprehensiveness of strategic decision processes: Extension, observations, future directions. Academy of Management Journal, 27: 445-466.

Fredrickson, J. W. and Mitchell, T. R. 1984. Strategic decision processes: Comprehensiveness and performance in an industry with an unstable 
environment, Academy of Management Journal, 27, pp. 399-423.

Fredrickson, J. W. and laquinto, A. L. 1989. Inertia and creeping rationality in strategic decision processes. Academy of Management Journal, 32: 516-542.

Graham, K. R., and Richards, M. D. 1979. Relative performance deterioration: Management and strategic change in rail-based holding companies. Academy of Management Proceedings: 10-112.

Greiner, L. E., and Bhambri, A. 1989. New CEO intervention and dynamics of deliberate strategic change. Strategic Management Journa, 10: 67-86.

Grimm, C. M. and Smith, K.G. 1991 Management and organizational change: A note on the railroad industry. Strategic Management Journal, 12: 557-562.

Hambrick, D. C. 1989, Guest Editor's Introduction: Putting Top Managers Bback In The Strategy Picture. Strategic Management Journal, 10: 5-15

Hambrick, D. C. and Schecter, S. M. 1983. Turnaround strategies for mature industrial-product business units. Academy of Management Journal, 26: 231248.

Hambrick, D. C. and Mason, P. A. 1984. Upper echelons: The organization as a reflection of its top managers. Academy of Management Review, 9: 193-206.

Hambrick, D. C. and D'Aveni, R.A. 1992. Top team deterioration as part of the downward spiral of large corporate bankruptcies. Management Science, 38 : 1445-1466.

Haveman, H. A. 1992. Between a rock and a hard place: Organizational change and performance under conditions of fundamental environmental transformation. Administrative Science Quarterly. 37: 48-75.

Hofer, C. W. and Schendel, D. 1978. Strategy Formulation: Analytical Concepts. West Publishing, St. Paul, MN.

House, R. J. and Aditya, R. N. 1997. The social scientific study of leadership: Quo vadis? Journal of Management, 23:409-473

House, R. J. and Shamir, B. 1993. Towards the integration of transformational, charismatic and visionary theories. Pp. 81-107 in M. M. Chemers and R. Ayman Eds.. Leadership theory and research:Perspectives and directions. San Diego, CA. Academic Press

House, R. J. 1977. A 1976 theory of charismatic leadership, in Hunt, J. G. and Larson, L. L. Eds Leadership: The Cutting Edge, Southern Illinois University Press, Carbondale, IL.

House, R. J. 1996. Path-goal theory of leadership: lessons, legacy and reformulated theory, Journal of Contemporaray Business, Vol. 3 No. 4, pp. 81-97

House, R. J. 1977. A 1976 theory of charismatic leadership. Pp. 189-207 in in J. G. Hunt and L. L. Larson Eds., Leadership: The cutting edge. Carbondale, IL: Southern Illinois University Press.

House, R. J., Wright, N. and Aditya, R. N. 1997. Cross cultural research on organizational leadership: A critical analysis and proposed theory. In P. C. Earley and M. Erez Eds.. New perpectives on international industrial and organizational psychology. San Fransisco, CA: Josey-Bass

Howell, J. M. and House, R. J. 1992. Socialized and personalized charisma: An essay 
on the bright and dark side of leadership. Unpublished manuscript. School of Business Administration, The Uiversity of Western Ontario

Jauch, L. R., Osborne, R. N., and Gleuck, W. F. 1980. Short-term financial success in large business organizations: The environment-strategy connection. Strategic Management Journal. 1: 49-63.

Keck, Sara L. 1991 Top executive team structure: Does it matter anyway? Paper presented at the Academy of Management Meeting, Miami.

Kelly, D., and Amburgey, T. L. 1991. Organizational inertia and momentum: A dynamic model of strategic change. Academy of Management Journal. 34: 591-612.

Knight, D., Pearce, C. L., Smith, K. G., Olian, J. D., Sims, H. P. and Flood, P. 1999. Top management team diversity, group process, and strategic consensus. Strategic Management Journal, 20: 455-465

Kotter, J. P. 1982. The General Managers. Free Press, New York, 1982

Landrum, N. E., Howell, J. P., and Paris, L. 2000. Leadership for strategic change. Leadership and Organization Development Journal, 213:150-156

Laughlin, R. C. 1991. Environmental disturbances and organizational transitions and transformations: Some alternative models. Organizational Studies. 122: 209232.

Lindhom, C. 1990. Charisma. Cambridge, MA: Basil Blackwell

Meyer, A. D. 1982. Adapting to environmental jolts. Administrative Science Quarterly, 27: 515-537.

Michel, J. G. and Hambrick, D. C. 1992. Diversification posture and the characteristics of the top management team. Academy of Management Journal, 35: 9-37.

Miller, D., and Friesen, P. H. 1980. Archetypes of organizational transition. Administrative Science Quarterly. 25: 268-299.

Mintzberg, H. and Westley, F. 1992. Cycles of organizational change. Strategic Management Journal. 13, 39-59

Mintzberg, H. 1973. The nature of managerial work. New York: Harper and Row.

Mintzberg, H., Ahlstrand, B., and Lampel. J., 1998. Strategy safari: a guided tour through the wilds of strategic management. New York, NY: Free Press

Nutt, P. 1987. Identifying and appraising how managers install strategy. Strategic Management Journal. 8: 1-14.

O'Reilly, C. A. and Sylvia F. F. 1989. Executive team demography, organizational innovation, and firm performance. Paper presented at the Academy of Management Meeting, Washington, DC.

Pettigrew, A. 1987. The Management of strategic changes eds.. Oxford: Basil Blackwell

Quinn, J. B. 1980. Strategies for change: Logical incrementalism. Homewood, IL: Irwin.

Rajagopalan, N and Spreitzers, G. M. 1996. Torward a theory of strategic change: A multi-lens perspective and integrative framework. Academy of Management Review. 22 1: 48 
Schendel, D. 1989. Introduction to the Second Special Issue 'on Strategic Leadership', Strategic Management Journal, 10, Special Issue: Strategic Leaders and Leadership Summer, 1989, 1-3

Schendel, D. E., Patton, G. R., and Riggs, J. 1976. Corporate turnaround strategies: A study of profit decline and recovery. Journal of General Management. Spring: 93-111.

Selznick, P. 1957. Leadership in administration: A sociological interpretation. Harper \& Row, New York. NY

Simons, T., Pelled, L. H., and Smith, K. 1999. Making use of difference: Diversity, debate, and decision comprehensiveness in top management teams. Academy of Management Journal, 42: 662-673

Simons, R. 1994. How new top managers use control systems as levers of strategic renewal. Strategic Management Journal. 15: 169-189.

Singh, J. V., House, R. J., and Tucker, D. 1986. Organizational change and organizational mortality. Administrative Science Quarterly. 31:587-611.

Smircich, L. and Morgan, G. 1982. Leadership: The management of meaning. Journal of Applied Behavioral Science, 18: 222257-273

Smith, K. G., and Grimm, C. M. 1987. Environmental variation, strategic change and firm performance: A study of railroad deregulation. Strategic Management Journal. 8: 363-376.

Smith, K. G., Smith, K.A., O'Baron, D. P., Olian, J. D., Sims, H. P., Scully, J., 1994 Top management team demography and process: The role of social integration and communication. Administrative Science Quarterly, 39, pp. 412-438

Tichy, N. M. and Devanna, M. A. 1986. The transformational leader, New York: Wiley Tushman, M. L., Virany, B., and Romanelli, E. 1985. Executive succession, strategic reorientations, and organizational evolution: The minicomputer industry as case in point. Technology in Society. 7: 297-313.

Wiersema, M. F., and Bantel, K. A. 1992. Top management team demography and corporate strategic change. Academy of Management Journal. 35: 91-121.

Yukl, G. A. 1989. Leadership in organizations, 2nd Eds. Englewood Cliffs, NJ: Prentice-Hall

Zajac, E. J., and Shortell, S. M. 1989. Changing generic strategies: Likelihood, direction, and performance implications. Strategic Management Journal. 10: 413-430.

Zajac, E.J. and Kraatz, M.S.1993. A diametric forces model of strategic change: Assessing the antecedents and consequences of restructuring in the higher education industry. Strategic Management Journal. 14: 83-102.

\footnotetext{
* Ayi Ahadiat adalah dosen Manajemen Strategik pada Jurusan Manajemen Fakultas Ekonomi Universitas Lampung, Mahasiswa Program Doktoral Manajemen FEB UGM. Kritik dan dan saran dapat langsung menghubungi penulis dengan alamat email a_ahadiat@yahoo.com
} 